\title{
Diversity of Insect Pests and their Natural Enemies Infesting Teak (Tectona Grandis, Verbenaceae) in Coastal Odisha
}

\author{
M.K. Tripathy* and M. Rout \\ College of Forestry, O.U.A.T., Bhubaneswar, India \\ *Corresponding author
}

\section{A B S T R A C T}

\begin{tabular}{|l|}
\hline K e y w o r d s \\
$\begin{array}{l}\text { Insect pest, Teak } \\
\text { defoliator, Sapling borer, } \\
\text { Teak skeletoniser }\end{array}$ \\
\hline Article Info \\
\hline $\begin{array}{l}\text { Accepted: } \\
12 \text { October } 2018 \\
\text { Available Online: } \\
10 \text { November } 2018\end{array}$ \\
\hline
\end{tabular}

\section{Introduction}

Teak Tectona grandis (Linnaeus), is one of the preferred timber species of Odisha as well as India. In India, it grows naturally in 9 million hectare of area and considered as one of the top five tropical plantation species of the world. About 187 insects species have been found feeding on living teak tree in India which includes 78 species from order Lepidoptera, 40 species from order Coleoptera and 18 species from order Orthoptera (Hutacharern and Tubtim, 1995). In fact, the total number of insect pests infesting this plant might be more because of report of additional species by several workers around the country after the base line report. The pests attacking
Teak Tectona grandis (Linnaeus), is the most preferred afforested species of Odisha. It is attacked by 42 species of insect pests out of which Hyblaea puera, Eutectona machaeralis, Proma plagiophelps, Orgia albipunctata, Oxya velox, Atractomorpha crenulata, Ferissia virgata, Celosterna scabrator, Aphis gossypii, Tricentrus bicolour, Podisus brevispinus were found as major pests. Out of the total reported species, 52\% were recorded as foliage feeders, $31 \%$ as sap feeders, $7 \%$ as stem borers and bark feeders each and 3\% recorded as root feeders. A total of 24 species of predators, parasites and pathogens including 5 species of bird predators were recorded from the experimental sites located in and around Bhubaneswr, Odisha. Majority of the natural enemies including the Entomogenic nematode Hexamermis sps. was recorded from the major defoliating pest, Hyblaea puera Cramer infesting teak in this region. teak are grouped into different categories viz., root and stem feeders as well as sap suckers.

Outbreak of these pests occurs almost every year in Odisha as well as in other teak growing regions of India. During these outbreaks in the early flushing period of teak, trees usually suffer a total defoliation, sometimes there is partial defoliation later in the growth season (Nair, 1988).

Hence in the present investigation an attempt is being made for bringing out a systematic documentation of all the insect pests attacking teak in the state as well as the occurrence of natural enemies of the major pests in the agro climatic condition prevailing in this region. 


\section{Materials and Methods}

Insect pests of teak, Tectona grandis have been studied from Bhubaneswar and its surrounding areas located withen60km radius both from natural as well as afforested plantations at fortnightly interval during the experimental period from June, 2016 to July, 2017. Flying and slow moving insects were collected by means of a swift net and preserved appropriately for identification. Immature stages of Lepidopterous and Coleopterous insects were reared in the post graduate laboratory up to adult stage in natural food medium in plastic cups of 4 inch diameter and 4 inch depth after following all the sanitation practices. Identification was established either by personnel experience or from entomology museum or by consulting professors of Entomology Department or from Internet sources or by following keys laid by established workers (Patil et al., 2016). Spiders, insect predators and parasites were identified either by directly collected from field or by rearing of field collected countable number of eggs. The identity was confirmed from bio-control laboratory of Entomology Department, College of Agriculture. Bird predators were identified by taking constant observation on their feeding habbit during the day time, taking their photograph and matching with standard monographs. Pathogens were identified in the same way from rearing of field collected eggs and confirming it in the bio-control laboratory or Nematology, Department of College of Agriculture, O.U.A.T., Bhubaneswar.

\section{Results and Discussion}

The results recorded in Table $1 \& 2$, Figures 1 $\& 2$ and plates 1 to 21 indicated that a total of 42 sps. of insect pests were recorded in Bhubaneswar and coastal region of Odisha. Out of them, 11 species were from Lepidoptera, 9 species from Coleoptera, 13 species from Hemiptera, 2 species from Isoptera, 6 species from Orthoptera and 1 species from Diptera order. Sap feeding Hemipterus pests were dominant, Lepidopterus insect pests were moderate followed by Coleopterus pests. Among the natural enemies, predators belonging to order Coleoptera were the dominant group in teak ecosystem of the zone. Five species of spiders, 5 species of birds, 5 species of hymenoptera, 1 species of orthoptera, 1 species of nematode and 1 species of NPV were also recorded. The sap feeding insects like jassids, mealy bugs, stink bugs, cow bugs, spittle bugs, frog hoppers were found mostly on the tender leaves and shoots. However, in the post rainy situation the stink bugs were also recorded from old leaves and found to be randomly distributed throughout the canopy and the details of each group of insects is described below.

\section{Foliage feeding insects of teak}

\section{Lepidoptera}

\section{Teak defoliator}

It is recorded as the major defoliating insect of teak. Caterpillars are feeding in open and deep. Variation in colour of larvae is observed as per soil, nature of host plants and climatic conditions. Polyphagus. The moth is medium sized, nocturnal and lays eggs in red coloured leaves of the shoot. Several outbreaks are observed in a single year depending on climatic condition.

\section{Teak skeletonizer}

Caterpillars are small, pale yellowish in colour and remain in false webbing over the leaves, mostly prefer the old leaves and become more abundant towards the end of the season. It feeds by skeletonising the leaves due to feeding on green matters, affected trees have a 
dry-fire scorched appearance from a distance. Oligophagus, also feeds on teak flowers and buds under certain conditions.

\section{Tussock moths}

Two species of tussock moths were recorded during Kharif and Rabi season. The caterpillars are distinct with alternate bristles and haired projection, Polyphagus, possesses urticating hairs. Adult females are flightless and with reduced wings and mostly nocturnal. Caterpillars are phytophagus.

\section{Bagworms}

Two species of bagworms were recorded mostly during Rabi season. The caterpillar was protected by a bag prepared out of stick and saliva and it protrudes to outside to feed on foliage by making circular holes. Very often attached to stem and pupae are found hanging from branches. Sexual dimorphism is well pronounced in adults of both the sexes.

\section{Serpentine leaf miner}

Minute black flies and maggots make serpentine mining on leaves which are minor in status. Losses are more pronounced in several field and vegetable crops.

\section{Black loopers}

Caterpillars are black in colour with white rings on abdomen. It forms a complete loop during walking. Found during Kharif and feeds on the leaves of all categories of plants.

\section{Unidentified caterpillars}

Two species of unidentified caterpillars were recorded during the study. One species was medium sized and sparsely hairy body, black head, seems to be polyphagus and found during winter. Causes minor damage. Other species was a large size caterpillar with smooth body and spotted at the dorsal side and appears during late Kharif season. It also causes minor damage.

\section{Coleoptera}

\section{Myllocerus beetle and Ash weevil}

Small grey coloured weevils with reduced snout. Four species were recorded as given in Table 1. Prominent white spots are present in some species whereas ash weevil possesses white colouration over the body. Both adults and grubs appear in large numbers at the initiation of monsoon and cause serious defoliation and thus causes more damage to seedlings. Also available in pole sized plants but not in large plants.

\section{Epilachna beetle}

Mainly acts as a pest of vegetables but also observed in teak seedlings. Adults are small beetles with yellowish brown in colour with black spots on thorax. Larvae are pale yellowish with spiny body and feeds on the green matter of the leaves.

\section{Tortoise beetle}

Small sized beetles, adults are colourful with tortoise like head covering. Both adults and grubs feed on the foliage mostly during summer months. It acts as a minor pest.

\section{Pumpkin beetle}

Small to medium sized beetles, slender, active in habit and mostly found during summer months. These are named according to the colour of wings of the body which is either red or black.

Both adults and grubs feeds on leaves of teak seedlings, causing minor damage. 


\section{Orthoptera}

\section{Grasshoppers and crickets}

Five species of grasshoppers including the brown grasshopper and one species of cricket (bush cricket) was recorded during the study.

Both nymphs and adults are polyphagus and causes extensive damage to seedlings throughout the year except in winter. Because of dark green colouration and bushy foliage, they are attracted towards the leaves.

\section{Sap feeding insects}

\section{Chinch bug}

Medium sized bugs, red in colour with black tips of hemelytra. Both nymphs and adults feed on sap by sucking through stylet. It is of minor importance and seen mostly in seedlings.

\section{Spittle bug}

Both nymphs and adults feed on sap by sucking through stylets. It is more prevalent during Kharif season. Nymphs are covered with frothy mass, hence protected from the action of natural enemies. Adults upon touch can jump up to $12 \mathrm{ft}$. Causes deforming of leaves and twigs.

Also ovipositionl punctures causes damage. Eggs and nymphs are mostly found in the underside of leaves of seedlings as well as larger plants.

\section{Stink bugs}

Three species of stink bugs (Degonetus serratus, Halyomorpha halys, Podisus brevispinus) were recorded during the study period. Both species were found throughout the year except in high summer. Nymphs and adults found in large numbers towards the top of large plants as well as seedlings and feeds on the cell sap by sucking. It causes minor damage and extent of loss is not established so far.

\section{Cow bugs}

Both nymphs and adults are of typical appearance due to presence of two numbers of prothoratic spines. Sucks the sap from leaves, shoot tips and feeds on it. It is more prevalent during Kharif season and in seedlings as well as large plants.

\section{Aphids}

One species of aphid (Aphis gossypi) was recorded. They are small, soft bodied, pyriform, black coloured sucking pests and feeds on the sap by sucking through stylets. Also secretes honeydew which invites sooty mould growth and turns the leaves black. Prevalent throughout the year in all categories of plants.

\section{Mealy bugs}

Three species were found in patchy distribution in plants of all age groups. Nymphs and adult females are soft bodied congregated in colonies towards seedlings or shoot tip and base of leaves, covered with white milky secretions over the body. It causes crinkling of leaves and twigs due to sucking of excess cell sap. It also secretes honeydew which invites sooty mould growth over the leaf surface.

\section{Green leaf hoppers}

These are pale green, small insects, which moves sidewise found on the under surface of leaves of seedlings and large plants mostly during summer season. It was observed causing minor damage. 
Table.1 Succession of different insect pests of teak at Bhubaneswar during the Experimental period (2016-17)

\begin{tabular}{|c|c|c|c|c|c|c|}
\hline Sl. no. & Common name & Scientific name & Order & Family & Pest category & Status \\
\hline 1. & Defoliator & Hyblaea puera & Lepidoptera & Hyblaeidae & Defoliator & Major \\
\hline 2. & Skeletonizer & Eutectona machaeralis & Lepidoptera & Pyralidae & Defoliator & Major \\
\hline 3. & Bag worm & Pteroma plagiophelps & Lepidoptera & Psychidae & Foliage feeder & Occasional; but Major \\
\hline 4. & Bag worm & Thyridopteryx ephemeraeformis & Lepidoptera & Psychidae & Foliage feeder & Occasional; but Major \\
\hline 5. & Tussock moth & Dasychira grisefacta & Lepidoptera & Lymantidae & Defoliator & Minor \\
\hline 6. & Tussock moth & Orgia albipunctata & Lepidoptera & Lymantidae & Defoliator & Minor \\
\hline 7. & Tortoise beetle & Aspidimorpha sanctaecrucis & Coleoptera & Chrysomelidae & Foliage feeder & Minor \\
\hline 8. & Grass hoppers & Oxya velox & Orthoptera & Acrididae & Foliage feeder & Major in seedling \\
\hline 9. & Grass hoppers & Oxya nitidula & Orthoptera & Acrididae & Foliage feeder & Major in seedling \\
\hline 10. & Grass hoppers & Atractomorpha crenulata & Orthoptera & Acrididae & Foliage feeder & Major in seedling \\
\hline 11. & Grass hoppers & Tettigonia viridisima & Orthoptera & Tettigonidae & Foliage feeder & Major in seedling \\
\hline 12. & Brown wing grass hopper & Arphia conspersa & Orthoptera & Acrididae & Foliage feeder & Major in seedling \\
\hline 13. & Cricket & Meconema thalassinum & Orthoptera & Tettigonidae & Foliage feeder & Major in seedling \\
\hline 14. & Cotton grey weevil & Myllocerus sp. & Coleoptera & Cucurculionidae & Foliage feeder & Major at the reach of monsoon \\
\hline 15. & Serpentine leaf minor & Liriomyza trifolii & Diptera & Agromyzidae & Foliage feeder & Minor \\
\hline 16. & Leaf beetle & Zygogramma heterothecae & Coleoptera & Chrysomelidae & Foliage feeder & Minor \\
\hline 17. & Leaf beetle & Unidentified & Coleoptera & Chrysomelidae & Defoliator & Occasional but major \\
\hline 18. & Leaf beetle & Henoseplichna vigintioctopunctata & Coleoptera & Coccinellidae & Foliage feeder & Minor \\
\hline 19. & Black-loppers & Hyposidra talaca & Lepidoptera & Geometridae & Defoliator & Occasional but major \\
\hline 20. & Hairy caterpillars & Unidentified & Lepidoptera & --- & Defoliator & Occasional but major \\
\hline 21. & Caterpillar & Unidentified & Lepidoptera & --- & Defoliator & Occasional but major \\
\hline 22. & Black pumpkin beetle & Aulocophera uncta & Coleoptera & Chrysomelidae & Foliage feeder & Minor \\
\hline 23. & Aphids & Aphis gossypii & Hemiptera & Aphididae & Sap feeder & Minor \\
\hline 24. & White stink bug & Degonetus serratus & Hemiptera & Pentatomidae & Sap feeder & Minor \\
\hline 25. & Asian stink bug & Halyomorpha halys & Hemiptera & Pentatomidae & Sap feeder & Minor \\
\hline 26. & Stink bug & Podisus brevispinus & Hemiptera & Pentatomidae & Sap feeder & Minor \\
\hline 27. & Leaf footed bug & Clavigralla gibbosa & Hemiptera & Coreidae & Sap feeder & Occasional \\
\hline 28. & Cow bug & Triceritrus bicolour & Hemiptera & Membracidae & Sap feeder & Minor \\
\hline 29. & Mealy bug & Ferissia virgata & Hemiptera & Pseudococcidae & Sap feeder & Minor \\
\hline 30. & Mealy bug & Pseudococcus filamentosus & Hemiptera & Pseudococcidae & Sap feeder & Minor \\
\hline 31. & Mealy bug & Pseudococcus citri & Hemiptera & Pseudococcidae & Sap feeder & Minor \\
\hline 32. & Spittle bug & Ptylinellus praefractus & Hemiptera & Cercopidae & Sap feeder & Minor \\
\hline 33. & Chinch bug & Lygaeus hospes & Hemiptera & Lygaidae & Sap sucking & Minor \\
\hline 34. & Leaf hopper & Tettigonia ferruginea & Hemiptera & Cicadallidae & Sap feeder & Minor \\
\hline 35. & Green Striped leaf hopper & Eurybrachys tomentosa & Hemiptera & Fulgoridae & Sap feeder & Occasional but major during rainy seasons \\
\hline 36. & Bark borer & Indarbela quadrinotata & Lepidoptera & Metarbelidae & Bark feeder & Major \\
\hline 37. & Termite & Neotermus sp. & Isoptera & Termitidae & Bark feeder & Major \\
\hline 38. & Termite & Odontotermes obesus & Isoptera & Termitidae & Bark feeder & Major \\
\hline 39. & White grub & Lachnosterna serrata & Coleoptera & Scarabidae & Root feeder & Major on seedlings \\
\hline 40. & Sapling borer & Sahyadrasus malabaricus & Lepidoptera & Hapialidae & Stem borer & Occasional but major \\
\hline 41. & Elaterid beetle & Adelocera modesta & Coleoptera & Elateridae & Stem borer & Minor \\
\hline 42. & Babul shoot and root borer & Celosterna scabrator & Coleoptera & Cerambycidae & Stem borer & Occasional but major \\
\hline
\end{tabular}


Table.2 Succession of different natural enemies of major pests of teak during the experimental period (2016-17) at Bhubaneswar

\begin{tabular}{|l|l|l|l|l|}
\hline \multicolumn{1}{|l}{ SI No. } & \multicolumn{1}{|c|}{ Name of the species } & \multicolumn{1}{|c|}{ Order } & \multicolumn{1}{|c|}{ Family } & Type \\
nature
\end{tabular}



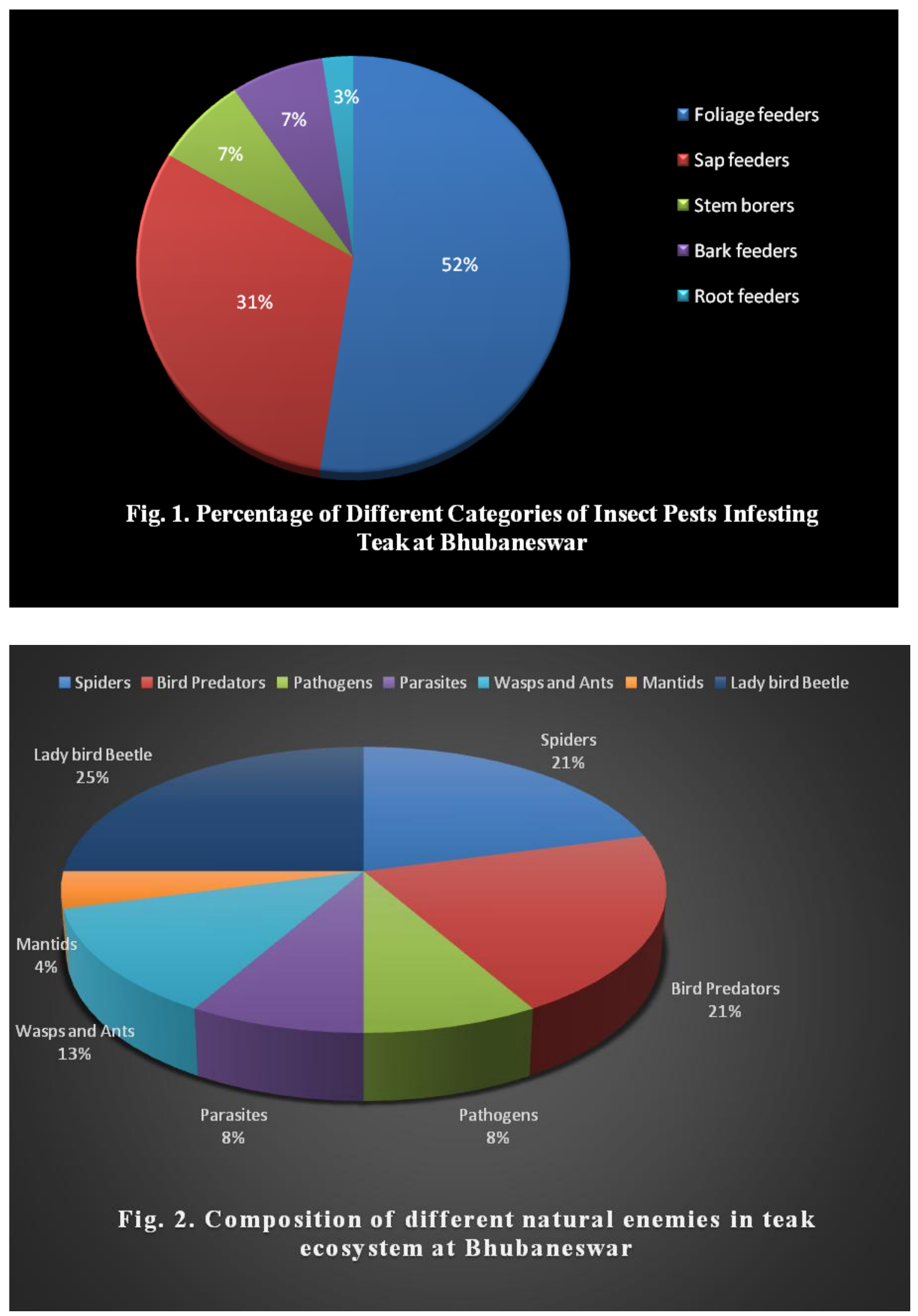


\begin{tabular}{|lll|}
\hline Adelocera modesta & Sahyadrasus malabaricus & Celosterna scabrator \\
\hline
\end{tabular}
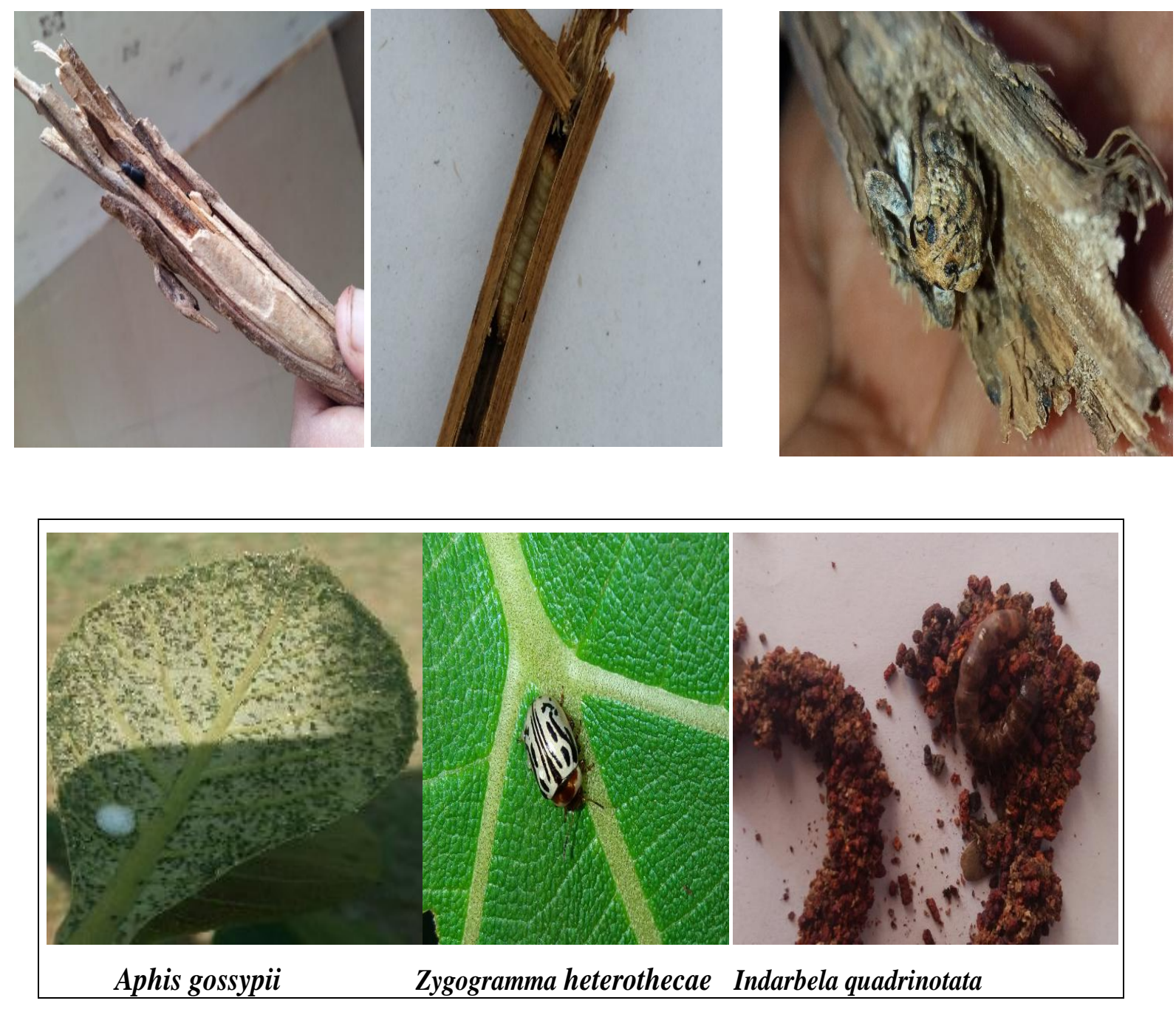

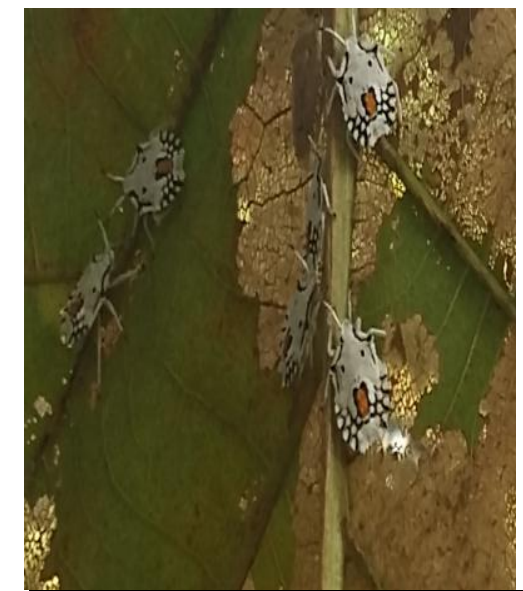

Degonetus serratus

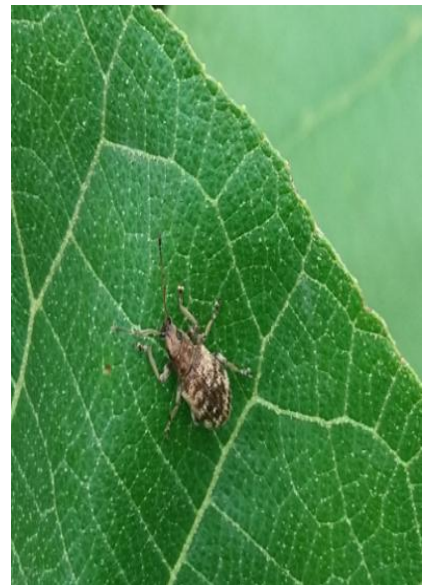

Myllocerus sp.

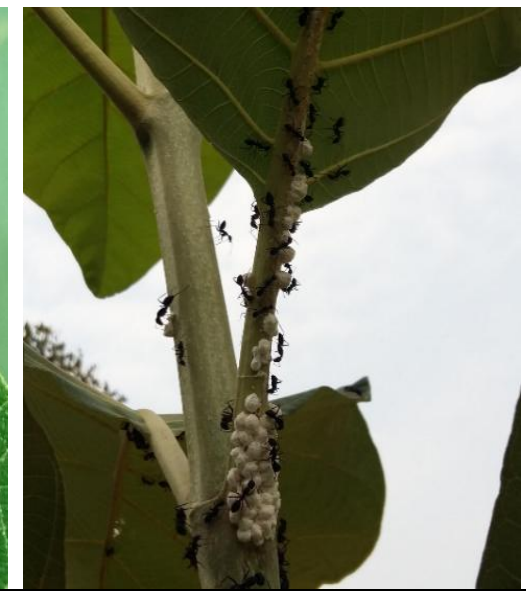

Pseudococcus filamentosus 

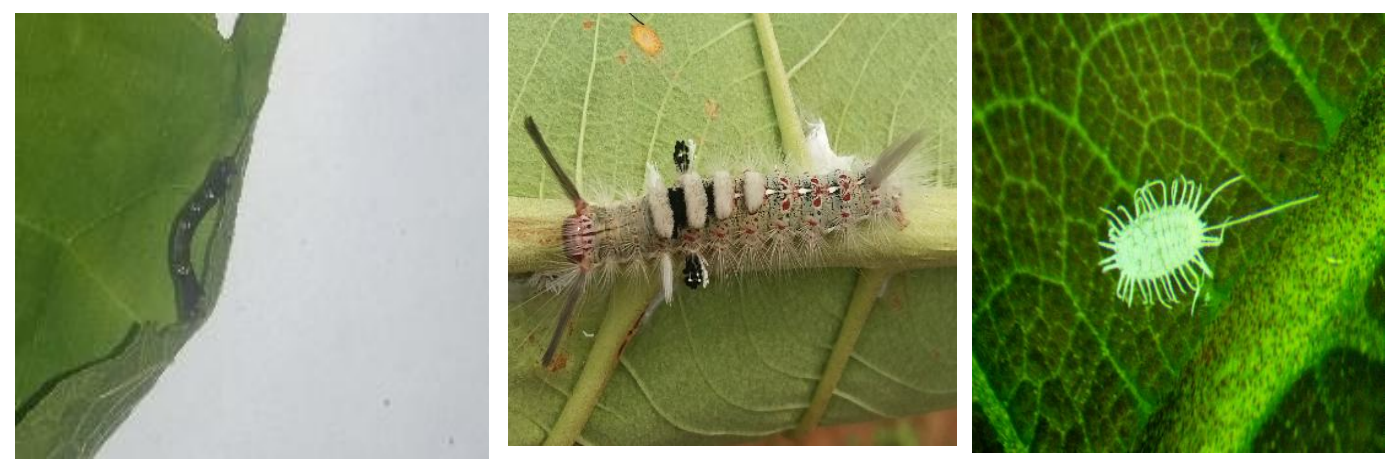

\section{Hyposidra talaca \\ Orgia albipunctata \\ Ferissia virgata}
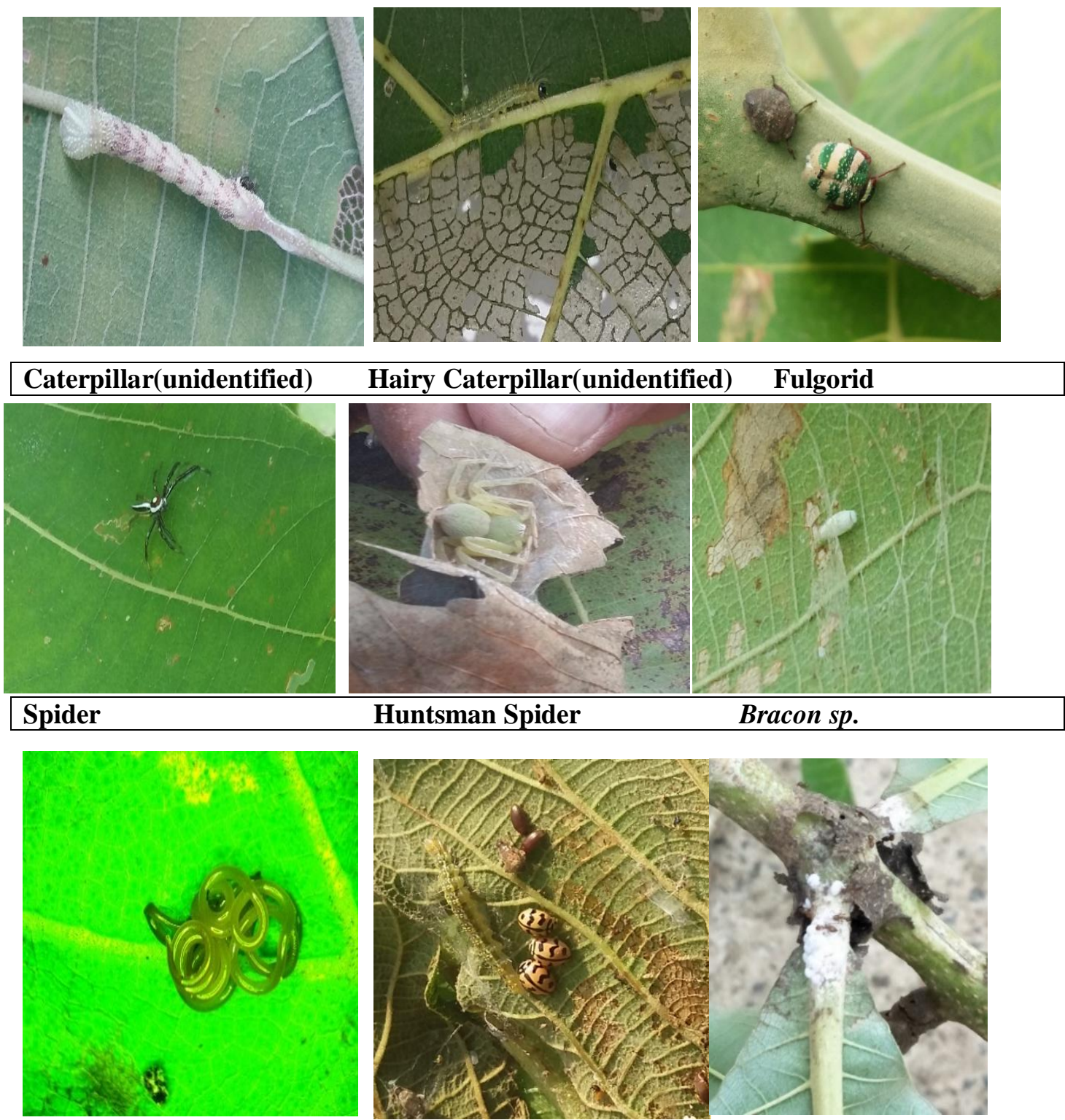

Hexamermis sp.

Lady Bird beetles

Ants 


\section{Frog hoppers}

Creamy white body with greenish bands present over the body. Most prevalent in forest nurseries located in forest ecosystem during Kharif season. Both nymphs and adults suck the cell sap.

\section{Bark Feeders}

\section{Termites}

Two species were recorded (Odontotermes obesus and Neotermus sp.) and very much prevalent during winter season in red dry soils conditions. The worker caste constructs mud galleries over the bark and feeds on bark materials. It causes mortality in fresh transplants. But larger plants get weakened and succumb to natural disasters.

\section{Bark eating caterpillar}

One species was found and its host range along with intensity of damage was studied. The larvae are robust rug us coloured with dark brown patches in each abdominal segments. Nocturnal in habitat and hides itself during day in the holes constructed at the place of branching. It feeds on the bark by remaining in galleries made out of frass materials of cellulose, excreta and saliva. The coloration varies. After being holed at the forked points the trees are succumb to natural disasters.

\section{Root feeders}

\section{White grubs}

The grubs are scarabaeform, cream colour, fleshy with well-developed strongly chitinized brown coloured mandibles. Feeds upon the root and causes mortality in seedlings. More prevalent in red sandy soils at the initiation of monsoon. Adults are reddish coloured medium sized beetles which lay eggs in soil.

\section{Stem borers}

\section{Teak sapling borers}

Adults are greyish brown moths and larvae enter into saplings after extracting a long cylindrical tunnel in the pith. Larvae were found with head towards tunnel mouth and this is covered with a silken mat work consisting of coarse saw dust like particles.

Larvae are yellowish white in colour with brown head. Pupation occurs at the bottom of the tunnel. Causes death of branches and small sized sapling and causes greater loss to pole sized plantations.

\section{Babul root and shoot borers}

The grubs bore the stem and moves down towards the root. During boring it oozes woody materials outside. Beetle is medium sized and a longicorn beetle, brown coloured. Abdomen is creamy white with prominent dark brown head.

From Figure 1 it is apparent that, among the insect pests $52 \%$ are foliage feeders, $31 \%$ are sap feeders, $7 \%$ are stem borers, $7 \%$ are bark feeders and $3 \%$ are root feeders.

A total of 24 species of predators, parasites and pathogens including 5 species of bird predators were recorded from teak ecosystem at coastal zone (Table 2 and Fig. 2). Majority of which were recorded from $H$. puera prepared leaf folds or larvae reared in the laboratory where as lady bird beetle predators were recorded from Aphids colonies. The Entemogenic nematode Hexamermis sp. was identified from laboratory reared final instar larvae of $H$. puera. NPVs were also observed during laboratory rearing of Teak defoliator 
larvae. Besides that major number of Hymenopterus parasites and predators were reported which includes Apanteles sp., Bracon sp., Myrmicaria brunnea, Solenopsis sp., and Ropalidia marginata, Coleopterus predators include, Cryptolaemus montrouzieri, Menochilus sexmasculatus, Coccinella undecimpunctata, Coccinella transversalis, Myzia interrpta, Brachycantha stephani. Five species of spiders were also found as major predators of insect pests infesting teak.

Earlier workers like Patil et al., (2016) from a survey in Western Moharastra also reported 3 species of homoptera, 23 species of coleoptera and 4 species of Lepidoptera infesting teak plants there. Katagall et al., (2000) from Bengaluru reported 45 species of insects infesting teak plants there which comprised of 22 species of defoliators, 19 species of sap feeders belonging to order Hemiptera and Thysanoptera and 4 species belonging to other orders. Nair (1998) from Kerala also suggested that Hyblea puera and Eutectona mecharalis were the most destructive pest of this plant, Attack of several species of stem borers to teak has been reported from the country and abroad by various workers like Baksha (1990) among which sapling borer was the important one. Babul root and shoot borer being a poly phagus one also attack teak and reported earlier by Sen Sharma (1983). Jha and Sen Sharma during, 2008 also reported white grubs along with termites as the main root feeding species in teak nurseries of M.P. Chatisgarh and Odisha. Another polyphagus pest reported here is bark eating caterpillar, Inderbella quadrinotata which has been reported from Punjab to infest70 plant species across the forest and avenue plantations (Verma and Khurana, 1978).

Several reports are also available in the country regarding natural enemy status of
H.purea and Eutectona mecharalis in natural condition. A total of 45 species of parasitoids, 108 species of predators(insects, predators and birds) of $H$. Puera and 75 species of parasitoids, 31 species of predatory insects, 38 species of predatory spiders many species of predatory birds of $E$ mecharalis was reported by Nair (2001). Mantids and wasps are reported to be the major predators of teak defoliator by Patil and Mohan Naik, (1998). Among the pathogens, NPV and nematode Hexamermis sps infesting teak defoliator was reported earlier by Sudheendrakumar et al., (1988) and Sandhu et al., (1993) from Neelambur, Kerala and Jabalpur respectively. However, in the present context the study has been confounded to documentation of insect pests attacking teak plants in this region along with a record of their natural enemies. However, more detail study on pest status, population dynamics, host range and biology is required to formulate a suitable control strategy for major insect pests attacking this plant in coastal Odisha.

\section{References}

Baksha, M. W. 1990. Some major forest insect pests of Bangladesh and their control Bulletin of Forest Entomology. Series 1,1-19(Forest Research institute, Chittagang)

Hutacharern, C and Tubtim, N. 1995. Checklist of forest insects in Thailand, Bangkok: Office of Environmental Policy and Planning, Ministry of Science, Technology and Environment.

Jha, L.K and Sarma P.K. 2008. A Manual of Forestry Extension Education. APH Publishing, 341.

Katagal, R.D, Kumar C.T.A. and Kurdikeri M.B. 2000. Insect pests of teak around Bangalore, Karnataka Journal of Agricultural Sciences, 13(1):176-179. 
Nair, K.S.S., Sudheendrakumar V.V., Varma, R. V and Mohanadas K. (1998), Tracing the Epicentres of Teak Defoliator Outbreaks in Kerala, KFRI Research Report No. 147, Preechi, India: Kerala Forest Research Institute.

Nair, K.S.S. 1988. The teak defoliator in Kerala, India, Dynamics of forest insect populations, EdA. A. Berryman, Newyork, Plenum press. US, 267-289.

Patil, S.U and Naik, M.I. 1998. Natural enemies of teak defoliator, Hyblaea puera Cramer and their seasonal incidence, Indian Journal of Forestry, 21(3): 253-255

Patil, S.S, Sutar M.V and Sathe TV. 2016. Diversity, Biology and Control of Insect pests of teak Tectona grandis (Linnaeus) from western Maharashtra, Bio Life, 4(1): 141-146.
Patil, S.U and Naik, M.I. 1998. Natural enemies of teak defoliator, Hyblaea puera Cramer and their seasonal incidence, Indian Journal of Forestry, 21(3): 253-255

Sandhu S., Rajak R.C. and Agarwal G.P. 1993. Microbial control agents of forest pests of Jabalpur, Annals of Forestry, 1 (2): 136-140

Sen-Sarma, P, K, 1983 Forest Entomology in India, Indian Rev of Life Sci, 3: 90-103

Sudheendrakumar, V.V, Mohamed Ali, M.I., Verma, R.V., 1988, Nuclear polyhedrosis virus of the teak defoliator Hyblaea puera, Journal of Invertibrate Pathology, 51: 307-308.

Verma, A.N. and Khurana A. D. 1978. Bark eating borers (Inderbela sp.) The pest of fruit, avenue and forest trees in India and South East Asia, Haryana Journal of Horticulture Science, 7(1-2): 40-46.

\section{How to cite this article:}

Tripathy, M.K. and Rout, M. 2018. Diversity of Insect Pests and their Natural Enemies Infesting Teak (Tectona Grandis, Verbenaceae) in Coastal Odisha. Int.J.Curr.Microbiol.App.Sci. 7(11): 1421-1432. doi: https://doi.org/10.20546/ijcmas.2018.711.164 